\title{
The Contributions Of Student Organization Involvement To Students' Self-Assessments Of Their Leadership Traits And Relational Behaviors
}

Lois J. Smith, University of Wisconsin, USA

John D. Chenoweth, University of Wisconsin, USA

\begin{abstract}
Many business schools designate leadership as a learning outcome for their undergraduates, but the question of how to teach leadership is challenging. Results of this study showed that students who were engaged in extracurricular student organizations rated themselves higher on both leadership traits and behaviors than those who were not involved in student organizations. Though faculty may not interact regularly directly with student affairs professionals, this study suggests that students learn holistically and across all their experiences, both inside and outside the classroom. Pairing coursework aimed at improving leadership capabilities with co-curricular organization activities that give students additional opportunities for trying out what they are learning in the classroom could improve intentionality and authenticity in students' educational experiences.
\end{abstract}

Keywords: Business Pedagogy; Leadership; Assessment; Student Organizations; Learning Outcomes

\section{INTRODUCTION}

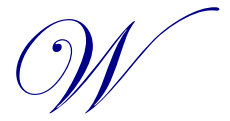

hat exactly is leadership? Business schools regularly include leadership as one of the skills that they want students to demonstrate as they graduate, but defining leadership is challenging, teaching it is difficult, and assessing it is demanding and sometimes ambiguous. Some educators measure leadership by inviting students to complete self-perception inventories of various traits, asking students to evaluate their own abilities or characteristics (Northouse, 2010). Others use intensive role-play simulations employing external evaluators (University of North Carolina at Chapel Hill, n.d.). Yet another method for assessing leadership is evaluation of field performance or practice drills (Department of the Army, 2006). Still others evaluate leadership abilities by asking students to provide self-reflection through papers or in-depth personal interviews (Logue, Hutchens \& Hector, 2005; Petriglieri, G., Wood, \& Petriglieri, J., 2011). Others have integrated service learning activities into their leadership courses, then asking students to reflect on their learning in those activities (Caro, Lirette \& Yest, 2013). Educators can use any of these measures to evaluate the leadership capabilities of individuals at one temporal point, but all of the measures vary in their abilities to give guidance as to how those tested actually learned to be (or not to be) leaders.

In classroom work, students study models and theories related to leadership, analyze cases, and work in teams (Foster \& Carboni, 2008; Northouse, 2010), but students appear to thrive when campuses work holistically and encourage students to engage with the wider university and to practice what they learned in classrooms through involvement in co-curricular activities or service learning projects associated with classwork (Astin, 1993; Athreya \& Kalkhoff, 2006; Caro, Lirette \& Yest, 2013; Dugan \& Komives, 2013; Pascarella \& Terenzini, 2005). As Hackman and Wageman (2007) aptly stated, “. . . there are no generally accepted definitions of what leadership is, no dominant paradigms for studying it, and little agreement about the best strategies for developing and exercising 
it" (p. 43). Still, higher learning institutions carry on, trying to give students more opportunities for leadership learning and engagement, regardless of the imperfections of the tools available.

This research focused specifically on the role of active membership in student organizations and students' perceptions of how these activities impacted their leadership abilities. The study surveyed business majors who were in their graduating semester at a large undergraduate business college with a student population of approximately 3400 . The survey asked seniors to report on which of several co-curricular activities they had been engaged (if any). Students then rated themselves on various leadership traits and behaviors. The contrast between students who were active in student organizations and those who were not will illuminate the perceived value of outof-class leadership experiences to student perceptions of leadership success. An exploration of the literature on cocurricular engagement and leadership traits will provide the background for the research hypotheses. This study extends and combines two streams of research. Specifically, it joins pedagogical research on the definitions and teaching of leadership in the classroom with student affairs research on leadership students gained through activities outside the classroom. Student self-ratings point to a possibility for common research and practice that helps students learn leadership skills through classroom experiences paired with co-curricular involvement and asks for cooperative work between faculty and student affairs staff.

\section{CO-CURRICULAR INVOLVEMENT AND STUDENT SUCCESS}

An exploration of the literature on the influence of co-curricular opportunities on students' development of leadership skills showed that students learn these skills at least in part by practicing them. When students are given the opportunity to work on real projects and problems in safe environments with obvious support of others such as faculty and staff advisors, they can experience cognitive and behavioral leadership learning (Hackman \& Wageman, 2007). Student organization activities provide this sort of experience for development as they give students the opportunity for peer interaction and leadership roles that provide a foundation for leadership training (Haber, 2011).

The scope of extracurricular involvement is extraordinarily wide, and various researchers have developed taxonomies for different categories of student organizations or co-curricular groups. Dugan (2013) provided a framework for differentiating and naming types of student groups. For example students could engage in "identity and expression" organizations such as theatre, arts, or international student, or sports organizations. Furthermore, he identified classes of opportunities such as arts organizations and academic groups and then added involvement in traditional campus-wide programming activities. Elkins, Forrester, and Noel-Elkins (2011) measured students' involvement with fourteen campus program areas including such activities as recreational sports, community service, conferences, student organization or clubs, student government, Greek organizations, and faith-based organizations, finding that students with moderate to high involvement in student activities perceived a greater sense of community, with variables loading on a factor related to teaching and learning. In creating a taxonomy for student involvement, Dunkel and Schuh (1998) classified student groups into categories of student government, Greek letter organizations (both social and professional), residence hall organizations, honoraries, military, sports, departmental/professional, and special-interest (such as ethnic, spiritual, service or hobby-oriented). However, regardless of how student clubs/organizations/activities were delineated, all offered opportunities for team projects, executive roles, and leadership practice.

Significant research supported the relationship between engagement in student clubs and the development of positive leadership traits and behaviors. For example, students who reported any amount of involvement in campus clubs had significantly higher scores across social change values for leadership development including collaboration, common purpose, controversy with civility, individual values, and citizenship (Dugan \& Komives, 2007). These results were generally not dependent on the type of student organization or club. Astin (1993) also found that "Student-student interaction had its strongest positive effects on leadership development" (p. 4), as well as academic success and critical thinking. Peer interactions that fostered leadership included curricular and cocurricular activities such as working on group projects for classes, tutoring other students, participating in intramural sports, socializing with someone from a different ethnic group, or spending time involved in student clubs. After peer group interaction, faculty interaction had the strongest effect on student development. Both peer-to-peer and faculty-to-student interactions were products of student organization involvement as the students planned and implemented the activities and the faculty advisors provided oversight to the clubs and guidance to the club officers. 
College graduates self-reported that leadership roles in extracurriculars had substantial impact on their development of leadership skills and interpersonal abilities that enhanced their job success. Informal, non-academic settings contributed substantially to students' career skills, according to their self-reports and ratings of skills (Pascarella \& Terenzini, 2005). When college students were engaged in social aspects of campus life, they advanced their learning and their personal development, and the relationship between academic success and cocurricular involvement was linear rather than inverted u-shaped (Huang \& Chang, 2004). Furthermore, in depth interviews, student leaders of extracurricular activities reported that their experiences in positions of responsibility were beneficial to their careers, academic success and skill development (Logue, Hutchens \& Hector, 2005). Phillips, McLaughlin, Gettig, Fajiculay, \& Advincula (2015) reported that pharmaceutical students found involvement in professional organizations had a strong influence on their leadership, teamwork, confidence and time-management abilities. Petriglieri, Wood \& Petriglieri (2011) summarized the relationship between classroom leadership content learning and experiential learning as an "active, personal, and social process" (p. 432).

Collegians could be engaged in one or a series of organizations over extended periods of time, even through their entire undergraduate experiences. Involved students expend substantial effort and maintain continued involvement as they lead events and projects, engage in community service, compete at professional conferences, receive judges' feedback on their performances, and work closely with peers towards common goals. They develop close ties that extend outside the classroom with faculty advisors and mentors. Research on the effects of involvement in co-curricular activities demonstrates that students have numerous opportunities for leadership experiences outside of the classroom. Students reported that co-curricular activities helped them learn to be leaders (Pascarella \& Terenzini, 2005). However, that training may be incomplete or out-of-context without students having the opportunity to digest and reflect on those experiences. Pairing leadership theory with student organization experience and allowing students to step back from their activities and evaluate them could give them the tools to evaluate, adapt, and improve their leadership skills further.

\section{LEADERSHIP QUALITIES, BEHAVIORS AND TRAITS}

Employing self-ratings of students' perceptions of strengths and abilities is a common method for assessing leadership traits and behaviors (Banta \& Kuh, 1998; Northouse, 2010; Pascarella \& Terenzini, 2005). Kuh (1993) wrote that students were both capable and insightful in describing and evaluating their experiences. Lists of traits and behaviors can be found in textbooks (Northouse, 2010), academic research (for example: Baker, 2008; Dugan \& Komives, 2007; Elkin, Forrest \& Noel-Elkins, 2011), the popular press (Farrell, 2011; Prive, 2012), and professional organizations' literature such as the Department of the Army (2006) or the American Library Association (Leadership traits, n.d.).

Haber (2011) noted the evolution of the definition of leadership began with qualities or characteristics of a person or a position. Over the past decades, leadership as a concept evolved to be more relational, process-oriented and systems-focused, emphasizing aspects of team-building and social interaction. Leadership identity development looked at processes by which individuals became leaders through peer interactions and ongoing membership in groups (Dugan \& Komives, 2007).

Recognizing the history of leadership definition and measurement, this research included self-reported measures of both individual traits and relational behaviors. We developed a list of traits and behaviors based on the many different types of source material described earlier. Table 1 shows the traits used along with their associated sources. In some cases, we took liberty with naming particular traits. For example, rather than using our chosen word, "optimism," Prive (2012) used the phrase "positive attitude," and rather than using "persistence," HERI (1996) referenced "commitment." We have attempted to be true to the concepts if not the exact wording of every author. In choosing traits to explore, we attempted to identify traits that students would be able to self-assess based on their student organization involvement. We recognized that the leadership literature was vast and that some of the existing leadership scales asked for external evaluation of leaders' abilities or before/after evaluations. Age appeared to be an important aspect of leadership behavior, and we respected the idea that traditional students would have had little direct experience in some aspects of leadership (Walter \& Scheibe, 2013). In choosing leadership traits and relational behaviors, we studied numerous sources, choosing characteristics that students could understand and with which they would have had experience in their organizational activity. For example, students may not have 
had military experiences or understand military-related terms, but the military leadership training materials are generally highly regarded and had many leadership traits that we found useful. Given the supposition that leaders develop and are not necessarily born, student leaders will have fewer experiences and need more development and might not have experiences related to some common traits (Day \& Sin, 2009). Others noted that the literature was filled with studies that have "theoretical and applied value" without being integrated with previous studies (Derue, Nahrgnag, et al. 2011). Table 1 shows the leadership traits that we identified as relevant to our student population along with references to the established scales that used these traits.

Table 1. Leadership Traits and Associated Sources

\begin{tabular}{ll}
\hline \multicolumn{1}{c}{ Trait } & \multicolumn{1}{c}{ Sources } \\
\hline Honesty & Athreya \& Kalkhoff, 2006; Farrell, 2011; Leadership traits, n.d.; HERI, 1996; Prive, 2012 \\
Responsibility & Department of the Army, 2006; Leadership traits, n.d.; Northouse, 2010 \\
Persistence & Farrell, 2011; HERI, 1996; Pincus \& Rudnick, 2013 \\
Optimism & Prive, 2012; Leadership traits, n.d. \\
Confidence & Astin, 1993; Department of the Army, 2006; Farrell, 2011; Leadership traits, n.d. \\
\hline
\end{tabular}

Table 2 shows the actions or relational behaviors that leaders exhibit as they engage with others. Our research asked students to rate themselves on the extent to which they displayed these skills. The behaviors we used for the survey and the sources in which they appeared are shown in this table. As with the traits, authors used different language to describe similar behaviors or skills. For example, we have used the phrase having "people skills" while Pincus \& Rudnick (2013) referenced treating people with respect and being empathy-oriented. For "teamwork," the American Library Association used labels of managing small group dynamics and partnerships (Leadership traits, n.d.). Rather than using the survey phrase "a model for others," the Department of the Army (2006) used the phrase "lead by example," and where we used "deal with failure," the Department of the Army suggested that leaders admitted when they were wrong, learned from their mistakes, and accepted setbacks. Using our nomenclature, leaders "deal with conflict" while in the Social Change Model, HERI (1996) and Dugan and Komives (2007) indicated that leaders had the skill to use civility as they dealt with controversy.

Table 2. Relational Behaviors/Skills and Associated Sources

\begin{tabular}{ll}
\hline \multicolumn{1}{c}{ Behaviors } & \multicolumn{1}{c}{ Sources } \\
\hline I have good people skills. & Farrell, 2011; Leadership traits, n.d.; Pincus \& Rudnick, 2013 \\
I am a model for others to follow. & Department of the Army, 2006; Leadership traits, n.d. \\
I deal well with stress. & Department of the Army, 2006; Leadership traits, n.d.; Northouse, 2010 \\
I deal effectively with failure. & Department of the Army, 2006; Leadership traits, n.d.; Farrell, 2011. \\
I am able to evaluate the talents of others. & Komives, Longerbeam, et al., 2006; Prive, 2012 \\
I am able to resolve conflicts. & Department of the Army, 2006; Dugan \& Komives, 2007; HERI, 1996 \\
I communicate clearly. & American Management Association, 2010; Astin, 1993; Athreya \& Kalkhoff, 2006; \\
& 2012; Pincus \& Rudnick, 2013 \\
I am a good listener. & Komives, Longerbeam, et al., 2006; Leadership traits, n.d. \\
I work effectively in teams. & American Management Association, 2010; Department of the Army, 2006; Komivє \\
& Longerbeam, et al., 2006); Farrell, 2011; Leadership traits, n.d. \\
I can develop a vision. & Athreya \& Kalkhoff, 2006; Department of the Army, 2006; Farrell, 2011; Pincus \& \\
& Rudnick, 2013 \\
I can execute a vision. & Department of the Army, 2006; Farrell, 2011 \\
I have innovative ideas for change. & American Management Association, 2010; Athreya \& Kalkhoff, 2006; Leadership \\
& n.d.; Prive, 2012 \\
I motivate others to do their best work. & Department of the Army, 2006; Northouse, 2010; Pincus \& Rudnick, 2013 \\
\hline
\end{tabular}

Recognizing the wide variety of student organizations and other opportunities for activities available at higher education institutions as well as the relationship between student engagement and leadership skill development, we have explored the extent of student involvement in a wide array of extracurricular activities, the contributions these activities made to students' leadership skills, and students self-reported leadership traits and skills. Because professional business student organizations play a prominent role in the students' lives in our college, we wanted to study the organizations' effects more purposefully and intentionally. As a result, we placed a special emphasis on student organization involvement. 
Based on previously cited research (Astin, 1993; Dugan \& Komives, 2007; Elkins, et al., 2011; Huang \& Chang, 2004; Kuh, 2008; Logue, et al., 2005), we propose that:

Undergraduates involved in student organizations as contrasted to those who were not involved in student organizations will have:

(1) Higher self-ratings on perceptions of their leadership traits.

(2) Higher self-ratings on perceptions of their relational leadership behaviors.

\section{RESEARCH METHODOLOGY AND RESULTS}

In spring semester of 2014, via email, we invited all graduating senior business majors at a large business school to complete an online survey concerning their leadership traits and behaviors and their campus engagement. The population of final semester graduating seniors was 511 students. Of that number, $149(29.2 \%)$ completed the survey (Table 3). For each of the results, we used t-tests to determine whether significant differences were found between the two groups: those students that participated in organizations and those that did not. Specifically, they were asked: "Have you been active in any type of student organization on campus during your time on campus? Please include only an organization in which you were truly involved, beyond simply paying dues." A second question asked them to indicate how long they had been involved with the organization, and $79.1 \%$ of those responding indicated that they had been members for 3 or more semesters; $48.3 \%$ had been involved for more than 4 semesters.

Table 3. Participation in Student Organizations

\begin{tabular}{lc}
\hline & Participated in at least one student organization \\
\hline Yes & $\mathrm{n}=100$ \\
No & $\mathrm{n}=49$ \\
\hline
\end{tabular}

\section{Self-Ratings of Leadership Traits}

For all measures, of leadership traits, students who participated in student organizations rated their leadership skills as higher than those who did not. Significant differences between those involved and those not involved occurred for some of the leadership traits (Table 4). The rating scale ranged from $1-5$ with 1 being "very strong" and 5 being "very weak" with a neutral central point. Specifically, those involved in student organizations rated themselves as significantly stronger in optimism and persistence than did students who were not involved in student organizations $(\mathrm{p}<.05)$.

Table 4. Self-Ratings on Leadership Traits

(Scale of $1-5$ with 1 = "very strong")

\begin{tabular}{lcccc}
\hline \multicolumn{1}{c}{ Item } & $\begin{array}{c}\text { Participated in Student } \\
\text { Organization Mean } \\
\text { (SD) }\end{array}$ & $\begin{array}{c}\text { Did not Participate in Student } \\
\text { Organization } \\
\text { Mean (SD) }\end{array}$ & $1.90(.984)$ & t (df) \\
\hline Confidence & $1.66(.809)$ & $1.29(.645)$ & $-1.48(147)$ & 0.0705 \\
Honesty & $1.17(.570)$ & $1.84(.590)$ & $-1.11(147)$ & 0.1334 \\
Optimism & $1.46(.758)$ & $1.65(.694)$ & $-3.05(147)$ & 0.0013 \\
Persistence & $1.43(.756)$ & $1.22(.468)$ & $-1.74(147)$ & 0.0421 \\
Responsibility & $1.15(.642)$ & & $-0.72(147)$ & 0.2353 \\
\hline
\end{tabular}

We combined these five traits in one sum in order to determine if students involved in student organizations rated themselves overall as having higher leadership traits than those not participating in student organizations. Cronbach's alpha (.78) for the resulting summed measure is greater than .7, an indicator of internal reliability. Cronbach's alpha computes one split-half reliability and then randomly divides the items into another set of split halves and recomputes all possible split half estimates of reliability. Cronbach's alpha is mathematically equivalent to the average of all possible split-half estimates on the resulting sum, involved students had a significantly higher rating of their traits than those not involved (mean difference $=-1.02, \mathrm{sd}=0.455, \mathrm{t}(147)=-2.25, \mathrm{p}=0.0127$ ). 
Survey results support our first hypothesis: that students involved in student organizations will exhibit higher self-ratings on perceptions of their leadership traits.

Self-Ratings of Relational Leadership Behaviors

Significant differences occurred between those involved in student organizations and those not involved for 8 of the 13 relational behaviors (Table 5). On a scale of $1-5$ with 1 being "very strong" and 5 being "very weak," those involved in student organizations rated themselves as having stronger people skills, serving as a model for others, dealing well with stress, dealing effectively with failure, resolving conflict, communicating clearly, working effectively in teams, and being a good listener $(\mathrm{p}<.05)$.

Table 5. Self-Ratings on Relational Leadership Behaviors/Skills (Scale of $1-5$ with 1 = "very strong")

\begin{tabular}{lcccc}
\hline & $\begin{array}{c}\text { Participated in Student } \\
\text { Organization } \\
\text { Mean (SD) }\end{array}$ & $\begin{array}{c}\text { Did not Participate in } \\
\text { Student Organization } \\
\text { Mean (SD) }\end{array}$ & t (df) & p \\
\hline People Skills & $1.29(.640)$ & $1.63(.755)$ & $-2.89(147)$ & 0.0022 \\
Model for Others & $1.49(.798)$ & $1.78(.823)$ & $-2.03(147)$ & 0.0220 \\
Deal well with Stress & $1.68(.920)$ & $1.95(.935)$ & $-1.73(147)$ & 0.0427 \\
Deal effectively with Failure & $1.76(.842)$ & $2.08(1.057)$ & $-2.01(147)$ & 0.0232 \\
Evaluate Talents of Others & $1.40(.696)$ & $1.55(.614)$ & $-1.29(147)$ & 0.0993 \\
Resolve Conflicts & $1.44(.715)$ & $1.71(.707)$ & $-2.21(147)$ & 0.0144 \\
Communicate Clearly & $1.50(.785)$ & $1.82(.727)$ & $-2.37(147)$ & 0.0096 \\
Work Effectively in Teams & $1.31(.706)$ & $1.69(.847)$ & $-2.92(147)$ & 0.0021 \\
Good Listener & $1.25(.626)$ & $1.47(.616)$ & $-2.02(147)$ & 0.0225 \\
Develop a Vision & $1.66(.819)$ & $1.86(.842)$ & $-1.37(147)$ & 0.0867 \\
Execute a Vision & $1.46(.716)$ & $1.59(.643)$ & $-1.09(147)$ & 0.1387 \\
Innovative Ideas for Change & $1.75(.978)$ & $1.98(.924)$ & $-1.37(147)$ & 0.0864 \\
Motivate Others & $1.53(.745)$ & $1.71(.645)$ & $-1.48(147)$ & 0.0705 \\
\hline
\end{tabular}

As a final step, we combined these 13 items into one scale in order to determine if students involved in student organizations rated themselves overall as having higher leadership behaviors than those not participating in student organizations. Cronbach alpha (0.91) for the resulting scale is greater than .7 , as an indicator of internal reliability. On the resulting scale, involved students had a significantly higher rating of their behaviors than those not involved (mean difference $=-3.32, \mathrm{sd}=1.24, \mathrm{t}(147)=-2.68, \mathrm{p}=0.0041$ ).

Our second hypothesis stated that students involved in student organizations would exhibit higher selfratings on perceptions of their relational leadership behaviors. The data trends support this hypothesis.

\section{Effect of Involvement in Multiple Student Organizations}

In order to determine the effect of involvement in multiple student organizations, we asked students if they had participated in a second student organization. While students involved in multiple organizations did rate themselves higher in terms of both leadership traits and relational behaviors, the difference was not significant (Table 6). Of the students who had been involved in one organization, $52.5 \%$ had been involved in a second organization as well.

Table 6. Effect of Participation in Multiple Student Organizations (Overall Traits or Characteristics summed score of $5-25$ with $5=$ "very strong") (Overall Skills or Abilities summed score of 13 - 65 with 13 = "very strong")

\begin{tabular}{|c|c|c|c|c|}
\hline Item & $\begin{array}{c}\text { Participated in Multiple Student } \\
\text { Organizations } \\
\text { Mean (SD) } \\
n=49 \\
\end{array}$ & $\begin{array}{c}\text { Participated in a Single Student } \\
\text { Organization } \\
\text { Mean (SD) } \\
n=45\end{array}$ & $t(d f)$ & $\mathbf{p}$ \\
\hline $\begin{array}{l}\text { Overall Traits or Characteristics } \\
\text { (summed score) }\end{array}$ & $6.95(.390)$ & $7.58(.245)$ & $1.32(92)$ & 0.0957 \\
\hline $\begin{array}{l}\text { Overall Skills or Abilities } \\
\text { (summed score) }\end{array}$ & $19.8(6.995)$ & $21.36(4.85)$ & $1.21(92)$ & 0.1142 \\
\hline
\end{tabular}




\section{Summary of Results}

Students who were involved in co-curricular campus organizations rated themselves higher on a series of related leadership traits including confidence, honesty, optimism, persistence, and responsibility, with significant differences in optimism and persistence. This finding supports the hypothesis that student involvement in extracurricular student organization activities led to more positive self-perceptions of leadership traits than for students who were not involved in those organizations.

For relational leadership behaviors, students active in co-curricular organizations also rated themselves significantly more positively on having stronger people skills, serving as a model for others, dealing well with stress, dealing effectively with failure, resolving conflict, communicating clearly, working effectively in teams, and being a good listener. For each behavior, students engaged in organizations self-rated themselves more positively than those students not involved, supporting the second hypothesis.

Students involved in more than one organization rated themselves more positively overall in traits and behaviors, but the differences were not significant, suggesting that one active and prolonged experience is as valuable as serial or multiple simultaneous experiences.

One limitation of the research project was the population from which the respondents were selected. The respondents originated from one large business college with dozens of active business student organizations and so would not be representative of all business schools. The leadership traits and actions were created with this specific student body in mind, and though the characteristics used were in many other scales and showed good results for Cronbach's alpha, we are not able to compare them with previous research results. Also, as with other studies using respondents' self-perceptions of leadership, we are unsure as to whether self-reports of attitudes and skills accurately reflect behaviors.

\section{DISCUSSION}

The results of this research support several previous studies published primarily in student affairs journals whose authors have argued for the importance of out-of-class leadership experiences and how those experiences enhanced classroom learning (Dunkel \& Schuh, 1998; Elkin, Forrester \& Noel-Elkins, 2011; Haber, 2011; Huang \& Chang, 2004; Logue, Hutchens \& Hector, 2005; Schuh, 1999). Astin (1993) wrote that "Evidence strongly suggests that ... learning is holistic rather than segmented, and that multiple forces operate in multiple settings to shape student learning and change in ways that cross the 'cognitive-affective' divide" (p. 629). Minority students who were involved in formal and social activities outside of the classroom earned higher grades overall, and expanded formal and informal social ties to others at higher education institutions, correlating positively to higher levels of satisfaction with education experiences for all students. Furthermore, students with these ties were less likely to leave their institutions (Fischer, 2007). Anecdotally, when graduates reflect on their undergraduate years, many times they will describe valuable learning experiences that occurred outside their traditional classrooms, whether through student organization involvement, internship experiences, or residence life activities. As Kuh (1993) wrote, students described their learning as happening “... at all times and in all places” (p. 88).

At the same time as students are learning through experience, they are gaining knowledge about the theory and concepts of leadership inside their classrooms with the help of talented faculty, well-written textbooks, team exercises, and written and oral assignments. These classroom activities are invaluable to their full understanding and knowledge of what leaders are and how they behave. Faculty and academic classroom activities alone cannot do all the work of developing undergraduates' intellectual and personal knowledge and skills, that learning also occurs where students spend the majority of their time, whether in employment, athletics, residence life, or social/professional settings (Dugan \& Komives, 2007). Because learning occurs holistically and across many different facets of students' experiences, the process of assessing common learning outcomes such as leadership could serve as a basis for collaboration for student affairs staff and faculty. Most academic and student affairs professionals do not collaborate in designing activities or assessing learning despite the fact that out-of-class activities are connected to important skill acquisition. Agreement across the academic and student affairs divide that students' lives are not parceled into discrete units of experience can lead to productive cross-university 
conversations about improving intentionality and designing experiences that would enhance professional and personal development (Banta \& Kuh, 1998) and improve leadership skills and abilities.

One method for using life experiences directly in classroom activities is a modification of traditional case analysis. Faculty have relied on case analyses to bring real world situations into the classroom, to give students the opportunity to apply theory to business situations, and to create and evaluate multiple possible strategic actions. Foster and Carboni (2009) suggested an alternative case analysis process in which students generated personal, experience- centered cases as foundations for developing behaviors and enhancing the practical pedagogy of leadership courses. Small groups worked together to reconstruct the issue and examine communication and thought/action congruency. They crafted their own interventions to their own leadership problems. Systematic reflection on the personal cases helped students act as leaders in their life experiences, moving from situation to theory, action, and reflection in what Foster and Carboni called a "Circle of Learning." With active co-curricular organization involvement, students had ready examples of leadership challenges that they faced in their club activities. Leadership skills they gained directly through club engagement included chairing meetings, writing reports, budgeting, communicating, traveling, competing, planning events, goal-setting, networking, resolving conflicts, assessing, recruiting, fundraising, and interviewing (Dunkel \& Schuh, 1998).

Another example of learning leadership beyond the confines of the classroom can be found in Caro, et al. (2013) and their class design using carefully designed service learning activities in a senior leadership seminar. They asked students to reflect on their experiences in a structured fashion, thereby blending the action with the functional understanding that those students encountered in their classroom.

Banta and Kuh (1998) provided two detailed examples of cross-divide partnerships between academics and student affairs. One was in the Sumter campus of the University of South Carolina where students had a formal student development transcript. When students participated in designated events either on or off campus, they earned involvement credits. Credits were recorded on the student development transcript that summarized their achievements as part of their career planning. The transcript then was monitored by students, faculty, and staff. Another approach to collaboration between academic and co-curricular activities that Banta and Kuh described was at James Madison University where campus groups linked general education learning outcomes with specific cocurricular activities, requiring collaboration between student affairs professionals and faculty in planning and executing activities.

With common leadership learning goals for academic and student affairs professionals, assessment might serve as an additional means of conducting research across barriers. At this point, two rich streams of separate research exist - one on the faculty/pedagogical side and the other on the student services side of universities. To develop leadership learning best practices, research combining these two lines of study would be exciting and could be fruitful in developing best practices for entire campus involvement and deep learning.

The higher education experience is filled with growth and learning. Students learn about leadership models, theories, and best practices in business classrooms. They engage in leadership behaviors of a wide-ranging nature in their co-curricular activities with the example studied here focusing on involvement in student organizations. Using assessment of leadership learning outcomes as an intentional means of pairing these two sides of learning - the thinking and the doing - holds promise for making the student experience cohesive and the staff experience collaborative, enriching the involvement of all invested groups.

\section{CONCLUSION}

Students who were engaged in co-curricular campus organizations rated themselves on their leadership traits and relational behaviors higher than students who were not involved in these activities. We understand that we studied correlation and not causation and so students who felt they were "born leaders" may have made the decision to become engaged while their more retiring counterparts may have stayed away from these activities. Still, given the value and confidence that involved students reported, intentional pairing of student and academic affairs activities with common learning goals such as leadership skills would be advantageous to all management students. 
Faculty and student organization advisors (who may or may not be faculty) might identify common leadership learning outcomes prior to the beginning of the term. Students would study leadership concepts and task characteristics in a classroom setting. For example, they might learn that when tasks are unclear or ambiguous, leaders should provide structure. When tasks are highly repetitive, leaders should give support (Northouse, 2010). Given this information, student organization advisors could ask their members to identify ambiguous and then repetitive tasks and set out differing strategies for leaders' actions that would provide structure or support, depending on the type of task. When students return to the classroom, they might reflect on the outcomes of their behaviors.

As Banta and Kuh (1998) pointed out, assessment activities can be one avenue for creating a bridge between classroom and co-curricular learning. One provides the theory, models, and history of leadership, the other the activity of leading. Both can entail thoughtful reflection on how to lead. The conversations regarding shared leadership learning goals that student affairs professionals and faculty have could lead to a synergy in which class assignments pair with organization activities while they aim at common goals. One of the best outcomes from assessment is discussion concerning what leadership is, how students learn to be leaders, how to measure it, and how well students perform, followed by a conversation on methods for improving leadership learning. The broader the group of professionals who share these common goals, and the more intentional they are, the better the reflection and the result.

\section{AUTHOR INFORMATION}

Lois Smith is an associate dean and professor of marketing in the College of Business and Economics at the University of Wisconsin - Whitewater. Her research interests focus on advertising to children and on pedagogy and she has co-facilitated numerous workshops for Liberal Education and America's Promise (LEAP) action teams on campus. She has published in the Journal of the Academy of Marketing Science, the Journal of Marketing Education, and the Journal of Services Marketing, among others. She is an active pro bono consultant for strategic planning processes in not-for-profit settings.

John Chenoweth is the dean of the College of Business and Economics at the University of Wisconsin Whitewater. He formerly served as an associate dean and chair of the department of Information Technology and Supply Management. His research has primarily focused on information technology education, online education and diversity. John co-directs the Wisconsin Center for Information Technology Services.

\section{REFERENCES}

American Management Association (2010). Critical skills survey. Education Digest, 76, 17-19.

Astin, A. W. (1993). What matters in college? Four critical years revisited. San Francisco: Jossey-Bass.

Athreya, K. S., \& Kalkhoff, M. T. (2006). The engineering leadership program: A co-curricular learning environment by and for students. Journal of STEM Education, 11, 70-74.

Baker, C. N. (2008). Under-represented college students and extracurricular involvement: The effects of various student organizations on academic performance. Social Psychology of Education, 11, 273-298. doi:10.1007/s11218-007$9050-\mathrm{y}$.

Banta, T. W. \& Kuh, G. D. (1998). A missing link in assessment. Change, 30, 40-47. Caro, C.A., Lirette, L., \& Yest, M. (2013). Redesigning MGMT 4010S: Creating a cause of social responsibility and social justice. American Journal of Business Education. 6 (2), 155-160.

Day, D. \& Sin, H. (2009). Leader development, identity and goal orientation: A study of personal change trajectories. Academy of Management Annual Meeting Proceedings, pp. 1-6.

Department of the Army (2006). Army leadership: Competent, confident, and agile. (FM 6-22). Washington, D.C.: Headquarters, U.S. Army.

Dugan, J. P. (2013). Patterns in group involvement experiences during college: Identifying a taxonomy. Journal of College Student Development, 54, (229-246).

Dugan, J. P. \& Komives, S. R. (2007). Developing leadership capacity in college students: Findings from a national study. A Report from the Multi-Institutional Study of Leadership. College Park, MD: National Clearinghouse for Leadership Programs.

Dunkel, N. W. \& Schuh, J. H. (1998). Advising student groups and organizations. San Francisco, CA: Jossey-Bass. 
Elkins, D. J., Forrester, S. A., \& Noel-Elkins, A. V. (2011). Students' perceived sense of campus community: The influence of out-of-class experiences. College Student Journal, 45, 105-122.

Farrell, R. (2011, Aug. 3). 23 traits of good leaders. Careerbuilder.com. Retrieved from http://www.careerbuilder.com.

Fischer, M. J. (2007). Settling into campus life: Differences by race/ethnicity in college involvement and outcomes. The Journal of Higher Education, 78, 125-156.

Foster, P., \& Carboni, I. (2009). Using student-centered cases in the classroom: An action inquiry approach to leadership development. Journal of Management Education 33, 676-697.

Haber, P. (2011). Peer education in student leadership programs: Responding to co-curricular challenges. New Directions for Student Services, 133, 65-75.

Hackman, J. R., \& Wageman, R. (2007). Asking the right questions about leadership: Discussion and conclusions. American Psychologist, 62, 43-47.

Higher Education Research Institute [HERI]. (1996). A social change model of leadership development: Guidebook version III. College Park, MD: National Clearinghouse for Leadership Programs.

Huang, Y., \& Chang, S. (2004). Academic and cocurricular involvement: Their relationship and the best combinations for student growth. Journal of College Student Development, 45, 391-406.

Komives, S. R., Longerbeam, S. D., Owen, J. E., Mainella, F. C., \& Osteen, L. (2006). A leadership identity development model: Applications from a grounded theory. Journal of College Student Development, 47, 401-408.

Kuh, G. D. (1993). Cultural perspectives in student affairs work. Washington, D.C.: American College Personnel Association.

Kuh, G. D. (2008). High-Impact educational practices: What they are, who has access to them, and why they matter. Washington, D.C.: Association of American Colleges and Universities.

Leadership traits. (n.d.). Retrieved November 27, 2013 from American Library Association website, http://www.ala.org/nmrt/initiatives/ladders/traits/traits.

Logue, C. T., Hutchens, T. A., \& Hector, M.A. (2005). Student leadership: A phenomenological exploration of postsecondary experiences. Journal of College Student Development, 46, 393-408.

Northouse, P. G. (2010). Leadership: Theory and practice. ( $5^{\text {th }}$ ed.). Thousand Oaks, CA: Sage Publications.

Pascarella, E. T., \& Terenzini, P. T. (2005). How college affects students. (Vol. 2). San Francisco, CA: John Wiley \& Sons.

Petriglieri, G., Wood, J. D., \& Petriglieri J. L. (2011). Up close and personal: Building foundations for leaders’ development through the personalization of management learning. Academy of Management Learning \& Education, 10, 430-450.

Phillips, J.A., McLaughlin, M. M., Gettig, J.P., Fajiculay, J. R., \& Advincula, M.R. (2015). An analysis of motivation factors for students' pursuit of leadership positions. American Journal of Pharmaceutical Education, 79 (1), 1-5.

Pincus, D. \& Rudnick, H. (2013). Leadership blind spot. BizEd, May/June, 40-43.

Prive, T. (2012, Dec. 19). Top 10 qualities that make a great leader. Forbes, Retrieved from http://www.forbes.com.

Schuh, J. H. (1999). Guiding principles for evaluating student and academic affairs partnerships. In Schuh, J. H. \& Whitt, E. (Eds.), Creating successful partnerships between academic and student affairs (pp. 85-97). San Francisco, CA: Jossey-Bass.

The University of North Carolina at Chapel Hill \& The Association to Advance Collegiate

Schools of Business [Simulation Manual]. (n.d.). Up your game: A leadership challenge.

Walter, F., \& Scheibe, S. (2013). A literature review and emotion-based model of age and leadership: New directions for the trait approach. The Leadership Quarterly, 24, 882-901. 